\title{
Illicit tobacco: Governments continue to blow smoke
}

$\mathrm{N}$ o one would dispute that measures to reduce smoking are one of the most effective public health initiatives that any community can deliver. Nor would they dispute that increases in the retail price of tobacco products are one of the most successful means of reducing tobacco consumption. In Canada, successive tax increases in the early 1990s drove down tobacco consumption before a concerted tobacco-industry campaign led to a rollback of taxes in 1994 - and increased rates of smoking. The reason behind that industry-led campaign was that tobacco smuggling was becoming rampant. And so it was. In fact the tobacco industry itself was shown to be a major player. Industry executives were subsequently jailed and tobacco companies themselves paid (astonishingly small) fines for their significant roles in deliberately marketing their products for illicit re-entry into Canada.

Smuggling of tobacco products continues in Canada, depriving governments of enormous revenues that could be applied to health services, increasing the likelihood of youth smoking and reducing incentives to quit among smokers of all ages. The problem principally involves the illicit distribution of tobacco products from four aboriginal communities: Kahnawake, Akwsesasne, Tyendinaga and Six Nations. The tobacco products in question come from several sources: many are manufactured on the reserves or in the United States (the RCMP notes that $90 \%$ of all smuggled tobacco emanates from the Akwesakne reserve which straddles Ontario, Quebec and the US); some are Canadian commercial brands smuggled from reserves without taxes being collected, and some are counterfeit brands imported into Canada. In each case, the o smuggled tobacco contributes, particularly in Eastern Canada, to a flood of cheap cigarettes with obvious health implications. It is no small irony that aboriginal communities, already confronting an array of health issues, are the victims of the widespread availability of the cheap cigarettes pro- duced in their midst. An astonishing 47\% of young First Nations males, $61 \%$ of young First Nations females and almost $60 \%$ of pregnant First Nations women are tobacco addicts. ${ }^{1}$ Researchers have suggested that illicitly manufactured cigarettes may contain more heavy metals and, as if it were possible, be potentially more harmful than their more legitimate, but still highly lethal, counterparts. The greatest health risk associated with contraband cigarettes is likely their price and their availability both contributing to greater rates of youth smoking and reducing incentives to quit.

All editorial matter in CMAJ represents the opinions of the authors and not necessarily those of the Canadian Medical Association.

The health community has made several carefully considered recommendations to governments. But the only actions on Parliament Hill or in Provincial Legislatures are the wringing of hands and the shrugging of shoulders. Meanwhile, hundreds of millions of dollars in public revenue are lost each year, cheap tobacco continues to wreak its deadly toll and organized crime flourishes in the face of governmental inertia.

Five important steps could quickly and effectively reduce the magnitude of this problem:

1. Increase the cost of tobacco manufacturing licenses and licensing bonds to a minimum of $\$ 5$ million ( $\$ 5000$ is the current fee). Realistic license fees and appropriate bonding practices will ensure that tobacco manufacturers, in any location, comply with appropriate provincial and federal legislation.

2. Prohibit the supply of raw materials (tobacco, papers, filters etc.) to unlicensed manufacturers.

3. Impose quota and refund systems for all tax-exempt tobacco products supplied to First Nation reserves. The quantity of tax-exempt tobacco products supplied to reserves can be controlled by establishing population-based quotas. Taxes should be collected at the time of manufacture and refunded on the basis of completed sales.

4. Introduce state-of-the-art tracking and tracing system for all manufactured tobacco products. This would allow effective monitoring of a product's distribution chain and any diversions, while facilitating the identification of illicit products.

5. Encourage First Nations to impose their own tobacco taxes, thus allowing them to lower consumption within their own communities, while developing revenue that could be reinvested in an array of social and health projects.

Is illicit tobacco more hazardous to health? Definitely. It undercuts public health approaches that reduce teenage smoking and serve as a stimulus to cessation; denies society revenue that could be used to support a variety of health initiatives and services; further erodes the health of First Nations communities, and contributes to increasing levels of organized criminal activities. Thoughtful governments would introduce forceful measures to deal with this burgeoning public health issue.

\section{Andrew Pipe CM MD \\ Chief \\ Minto Prevention and Rehabilitation Centre \\ University of Ottawa Heart Institute Ottawa, Ont.}

\section{REFERENCE}

1. Assembly of First Nations. First generation, second generation: an enhanced First Nations tobacco strategy. Submission to the president of the Treasury Board Secretariat, the Minister of Finance and the Minister of Health, June 2007. Ottawa (ON): The Assembly; 2006. Available: www.afn.ca/cmslib/general/Proposal\%20for\%20a\%20new\%20First $\% 20$ Nat ions\%20Tobacco\%20Cessation\%20Strategy.pdf (accessed 2009 Sept. 3).

Have you got an opinion about this article? Post your views at cmaj.ca. Potential Salon contributors are welcome to send a query to salon@cmaj.ca 